\title{
RESEARCH OF THE COMPOSITION OF OXIDE LAYER AND CORN OF THE KLYSTRON CATHODES WITH DIFFERENT DEGREE OF DEVELOPMENT
}

\author{
S.O. Vangha, R.M. Dronov, V.O. Mats, O.V. Medvediev, V.Yu. Tytov, Yu.D. Tur, I.O. Chayka, \\ E.A. Yaroshenko \\ National Science Center "Kharkov Institute of Physics and Technology", Kharkiv, Ukraine \\ E-mail: tur@kipt.kharkov.ua
}

In accordance with the work program for the restoration of klystrons, a cycle of studies was carried out, which includes X-ray fluorescence analysis of the composition of the emitter layer and core of oxide cathodes with different degrees of operating time. Studies have been conducted to assess the possibility of using and predicting the resource, both restored and used cathodes. Studies were conducted to assess the possibility of using and predicting the resource, both restored and used cathodes. The analysis was performed using a Bruker S8 TIGER WDXRF spectrometer (X-ray tube power $4 \mathrm{~kW}$, Rh-cathode, current up to $170 \mathrm{~mA}$, voltage up to $60 \mathrm{kV}$ ), with Spectra Plus software package. Comparative analysis of the data obtained for emitters with different degrees of development can provide a fairly reliable estimate of the efficiency and resource of the cathodes.

PACS: $29.25 \mathrm{Bx}$

\section{FORMULATION OF THE PROBLEM}

At present, in the research complex "Accelerator" NSC KIPT there are in constant operation 5 accelerator complexes containing 8 microwave stations. As electron sources of high-frequency power, linear electron accelerators use pulsed klystron amplifiers of the Aurora type at a frequency of $2797 \mathrm{MHz}$, with a pulsed output power of up to $20 \mathrm{MW}$ and an average of $2.6 \mathrm{~kW}$. One of the reasons for klystron failure is the loss of cathode emissions. In klystrons of the Aurora type, an oxide barium cathode is used. It is known [1] that the emission properties of the oxide cathode directly depend on the composition of both the emitting layer and the core. Therefore, the task was to study the structure of the cathodes in order to predict the term of further operation and restoration of emission properties.

\section{OBJECT OF RESEARCH}

The cathode used in klystrons of the Aurora type is a nickel core with reducing additives made by compressing PNE-1 powder with a surface layer of the active substance in the form of a solid solution of crystals of barium and strontium or barium, strontium and calcium (BaSrCa) $\mathrm{O}$ crystals. The principle of operation of any cathode is based on the process of electron emission from its surface. If we consider the oxide cathode, then such a surface are barium atoms. The durability of the oxide cathode is determined by the fact that the oxide layer is gradually depleted in barium atoms. The nickel base that the cathode core consists of is used for a number of reasons:

- low operating temperature, when viewed from the point of view of the rate of evaporation of the metal and its mechanical properties;

- the proximity of the coefficients of thermal expansion of nickel with oxide coating;

- high chemical stability with respect to the oxide layer and gases released during thermochemical treatment;

- low evaporation rate of the active substance from the surface of nickel;

- wide possibilities of shaping, ease of processing.
The active layer of the cathode is formed at the stages of pumping and training. As the starting material that is applied to the core surface, triple carbonate $\left(\mathrm{BaCO}_{3}\right.$, $\mathrm{SrCO}_{3}, \mathrm{CaCO}_{3}$ ) is used in the ratio: 47:43:10\% (in molar fractions). These ratios provide the highest emissivity of the cathodes at a given temperature [2]. Organic binders are used to fix the carbonate coating on the cathode core.

The formation of the active layer of the cathode should be divided into three stages:

1. Decomposition of a binder (binder) into gaseous products and a carbon residue;

2. The conversion of alkaline earth metal carbonates to oxides, the main degassing of the oxide layer;

3. The final degassing - the formation of an active oxide layer.

Binder decomposition - begins at a temperature of 423 and ends at $773 \mathrm{~K}$. The binder decomposes with the release of volatile neutral monomers and a very small carbon residue in the coating. The resulting gaseous products are able to oxidize the surface of the parts of the device, and the presence of a significant carbon residue can get into the cathode coating. As the cathode temperature rises further, carbonate dissociation begins with the formation of alkaline earth metal oxides. The most effective cathode degassing occurs in the temperature range $900 \ldots 1100 \mathrm{~K}[1]$. In this case, the process proceeds smoothly without breaking the coating and ejecting individual particles from it.

Coating activation - the process of enrichment of metal oxides with barium atoms begins already in the process of decomposition of carbonates, since at higher temperatures in vacuum oxygen atoms are removed in larger quantities than barium atoms. As the cathode temperature increases, the dynamic equilibrium shifts toward a higher concentration of excess barium atoms in the oxide layer, where $\mathrm{BaO}$ is chemically reduced using additives in the core material. Alkaline earth metal oxides cannot be reduced using pure nickel. Therefore, to activate the oxide cathode, additives of magnesium, calcium, zirconium or tungsten are added to nickel; in addition, additives, being electropositive elements, reduce the electron work function. Also, adding additives can achieve a significant reduction in the time spent on pumping, as 
well as lower the working temperature of the cathode. In a simplified form, the model of the oxide cathode can be represented as follows, starting with the operation of the simplest system - single-crystal barium oxide at elevated temperature in vacuum:

1. Due to thermal dissociation and evaporation, barium oxide $(\mathrm{BaO})$ passes from a composition with an excess of oxygen $(\mathrm{BaO}) \mathrm{O}$ to a composition with an excess of barium $(\mathrm{BaO}) \mathrm{Ba}$. During the calcination of barium oxide in vacuum, predominant oxygen evaporation occurs, as a result of which an excess of barium accumulates in the condensed phase. As an excess of barium is accumulated, the rate of oxygen evaporation decreases, and the rate of barium evaporation increases to a dynamically stationary state, when the rate of evaporation of the components is proportional to their concentration in the condensed phase and the composition of the compound remains unchanged until complete evaporation. Barium oxide in this state is a system with an excess of barium in the bulk, and especially on the surface of the crystal, and is a semiconductor with a high density of surface states. The durability of such a cathode (in the absence of the influence of secondary factors on the dynamics of the processes) is determined by the supply of the active substance and its evaporation rate.

2. The transition from barium oxide $(\mathrm{BaO})$ to solid solutions of alkaline earth metal oxides - (BaSrCa) O requires a more complex model. First, a slightly higher energy of interaction of barium with oxides of strontium and calcium, apparently, contributes to the concentration of excess barium on the surface of the crystals of the oxide layer and the deformation of its electronic states. All this together provides a decrease in the effective value of the work function by several tenths of electron-volts. Secondly, due to the higher evaporation rate of barium oxide compared with strontium and calcium oxides, the surface of the oxide layer is depleted in barium during cathode operation. The stability of the surface composition is provided by the balance of the rates of entry and evaporation of barium from the surface. In this regard, the volume of the layer is a reservoir of the active substance, which allows the composition of the surface layer of the cathode to remain unchanged through the processes of evaporation, migration, and diffusion. At the cathode operating temperature, the rate of migration over the surface of the crystals and Knudsen evaporation is equal to or greater than the rate of evaporation of barium from the surface of the oxide layer. The diffusion rate of barium in the bulk of the crystals is much less than the rate of its evaporation. Therefore, after evaporation of barium from the surface layer of all crystals of the oxide layer, intense depletion of the cathode surface layer begins with a corresponding change in its properties. Thus, unlike barium oxide, the life of a real cathode is determined by the evaporation of a small part of the total supply of barium oxide almost exclusively from the surface layer of crystals.

The selection of the emission current from the cathode affects the properties of the cathode and its operability: it accelerates the activation of the oxide layer and the evaporation of oxygen, heats the layer with Joule heat, and in large fields causes electric breakdown of the layer. The effect of current on the properties of the cathode increases with decreasing temperature (since this increases the voltage gradient in the oxide layer), with increasing thickness and porosity of the layer, with an increase in the electric field in it [2].

The subject of research in this work is the elemental composition and structure of the emitter and core. Samples of a new cathode and cathode with an operating time of 7000 hours were selected as objects of study. The samples are disks cut from cathodes (Fig. 2) with a diameter of $32 \mathrm{~mm}$ in an amount of 2 pieces from each cathode. In one of every two samples, the active oxide layer was removed to study the core in its pure form (Fig. 1).

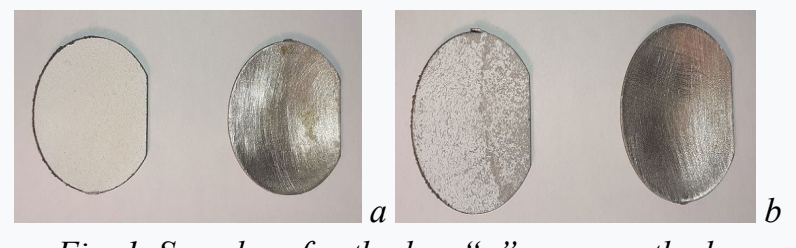

Fig. 1. Samples of cathodes: “a”- new cathode; " $b$ " - spent 7000 hours

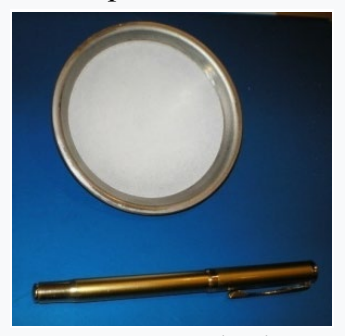

Fig. 2. Cathode

\section{EXPERIMENTAL TECHNIQUE}

The studies were performed using an X-ray fluorescence spectrometer (Fig. 3) with wave dispersion S 8 Tiger (Bruker AXS GmbX, Germany). The spectrometer is equipped with an OEG 95LT X-ray tube with an $\mathrm{Rh}$ anode with a maximum power of $4 \mathrm{~kW}$ and a current of up to $170 \mathrm{~mA}$, a set of crystal analyzers, flow-proportional and scintillation detectors, collimators, as well as $\mathrm{Al}$ and $\mathrm{Cu}$ filters of various thicknesses. The spectrometer is controlled and spectral data is processed using the Spectra Plus software package, which includes software for semi-quantitative (non-standard) express analysis of samples of unknown composition. To take into account the effects of inter-element influence, a model of corrections in concentration with theoretical $\alpha$-coefficients is used, based on the method of fundamental parameters [3]. The conversion of the intensity of the measured analytical line into the content of the determined element is carried out using the following expression:

$$
C_{i}=a_{0}+a_{1} \cdot I_{i} \cdot\left(1+\sum_{i \neq j} \alpha_{i j} \cdot C_{j}\right),
$$

where $C_{i}$ is the concentration of the element being determined; $a_{0}, a_{1}, \alpha_{i j}$ are the coefficients determined using linear regression; $I_{i}$ is the intensity of the analytical line of the determined element; $C_{j}$ is the concentration of the element that affects the determination of the intensity $I_{i}$.

The diameter of the samples $(32 \mathrm{~mm})$ was selected in accordance with the dimensions of the measuring chamber of the spectrometer, in the future it is planned to alter the chamber to the size of the cathode to ensure non-destructive testing. The measurements were carried out in vacuum. 


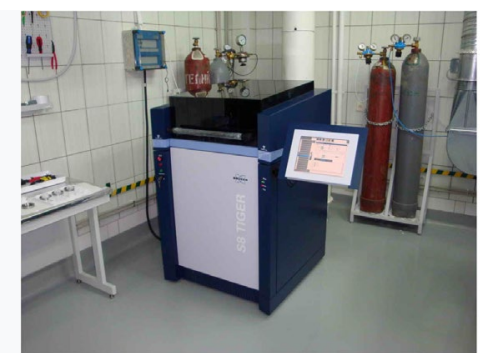

Fig. 3. X-ray fluorescence spectrometer $S$ S Tiger (Bruker AXS GmbX, Germany)

\section{RESULTS AND DISCUSSION}

As noted above, the emissivity of the cathode directly depends on the number of atoms of the active substance in the oxide layer and the atoms of the additive elements in the core. By X-ray fluorescence analysis, the spectra of elements were obtained: from the oxide layer: $\mathrm{Ni}, \mathrm{Sr}, \mathrm{Ba}, \mathrm{Ca}, \mathrm{Na}, \mathrm{S}$; from core material: $\mathrm{Ca}, \mathrm{Sr}$, $\mathrm{Na}, \mathrm{Fe}, \mathrm{Si}, \mathrm{Mg}, \mathrm{S}, \mathrm{Co}$. The choice of elements is determined by the chemical composition of the core material (PNE-1) according to GOST No. 9722-97. By the intensities of the lines of the elements, one can judge the quantitative composition of the oxide layer and core. In Fig. 4 shows the spectra of elements (a) the oxide layer of the new cathode, (b) the oxide layer of the spent cathode, (c) the core of the new cathode, and (d) the core of the spent cathode. For a more visual illustration in Fig. 5 shows the data of the intensities of the spectrum lines in the form of histograms. The above distributions illustrate the redistribution of elements during cathode operation due to diffusion [4]. A noticeable decrease in the intensity of the line of elements in the spent cathode demonstrates a decrease in the number of atoms of active elements both in the oxide layer and in the core material. A typical illustration is an increase in the number of core atoms $(\mathrm{Ni}, \mathrm{S})$ compared with the number of atoms of the oxide layer in the spent cathode (see Fig. 5,a,c). In Fig. 6 shows the surface of the spent oxide layer; the surface of the spent (a) and new (b) cathode oxide layer is shown at an increase of 50 times. The oxide layer of the spent cathode is more porous compared to the new one, mechanically destroyed in some places, core material is visible. This surface character arises, not only due to depletion (a decrease in the number of atoms of the main element), but also, possibly, due to foci of local heating.

The occurrence of foci of local heating can be explained by the following features:

- in different areas of the oxide layer, the resistance and emissivity are different;

- the oxide layer has a large resistance, therefore, its heating by the cathode current is comparable with heating from the glow current;

- with increasing temperature of the oxide layer, its resistance decreases, since the oxide layer is a semiconductor.

The cathode current is distributed so that large currents flow in areas with lower resistance and higher emission ability. In these areas, the heating intensifies, as a result of which the resistance decreases and the electron yield increases. Subsequently, the current value increases. Hot spots can also occur due to ion bombardment of the cathode surface. The general nature of the distributions and microscopic studies indicate the level of depletion of the spent cathode, which inevitably leads to a loss of emission.

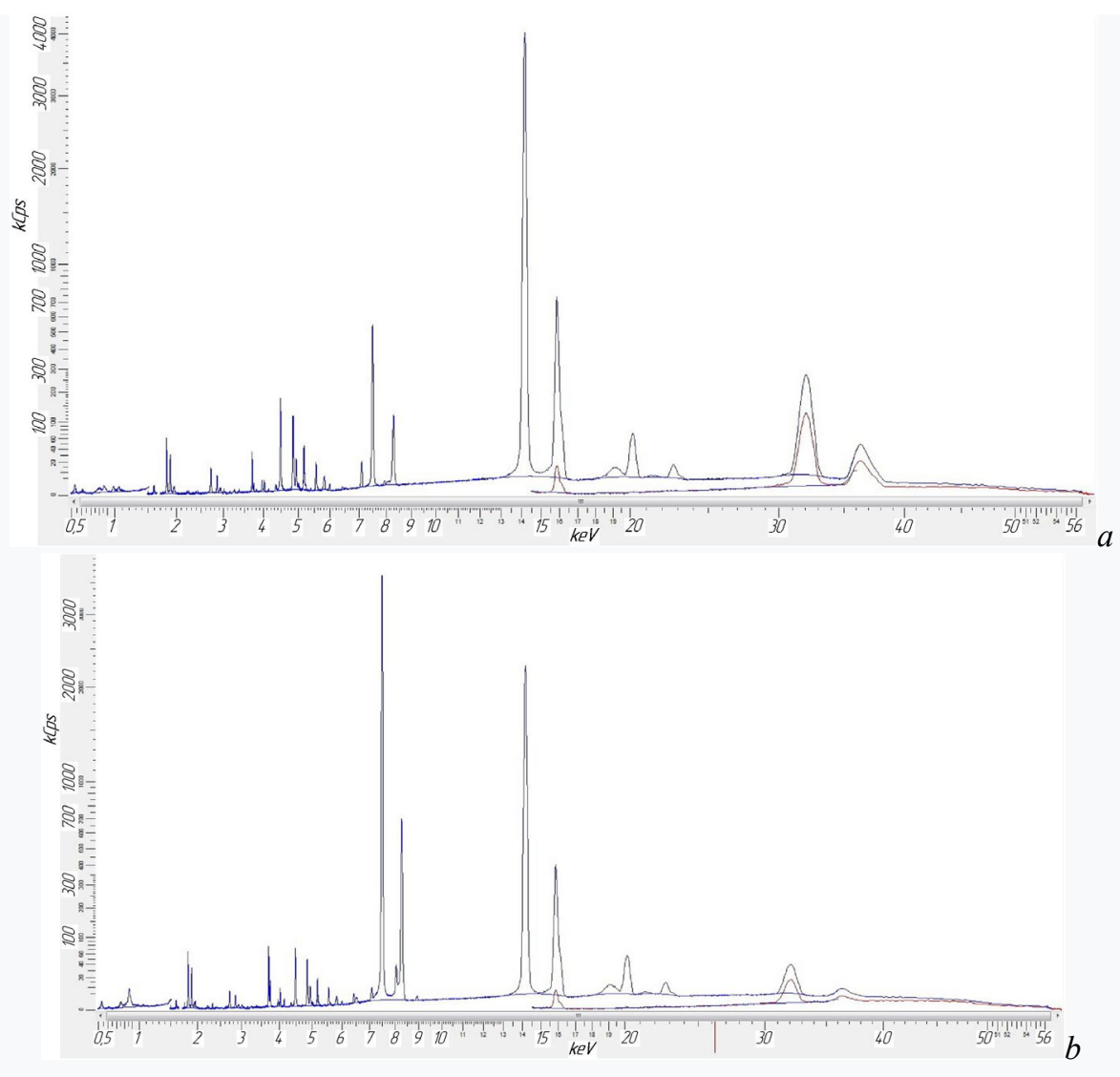



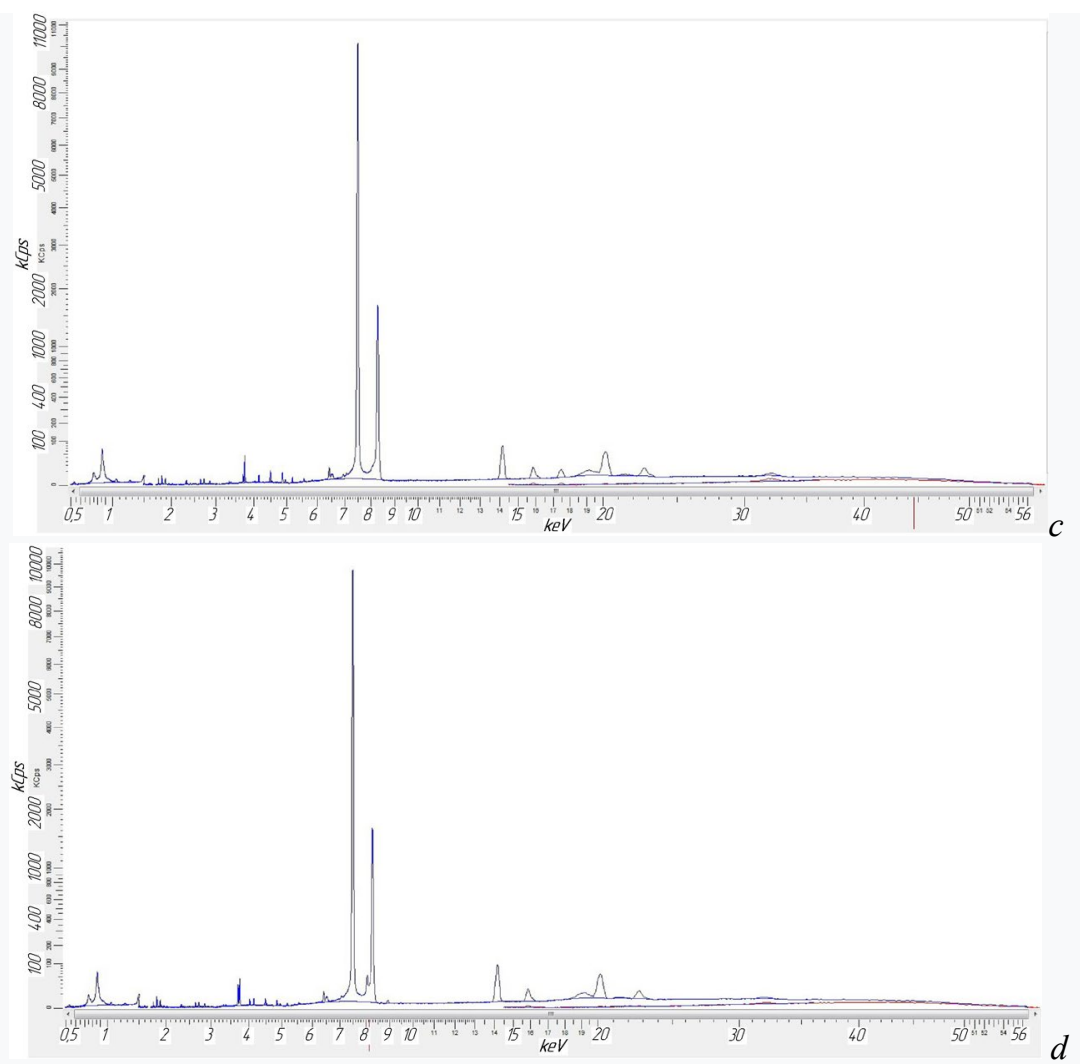

Fig. 4. Spectra of elements of an oxide layer of a new cathode (a); spectra of elements of an oxide layer of a spent cathode (b); spectra of elements of a core of a new cathode (c); spectra of elements of a spent cathode core (d)
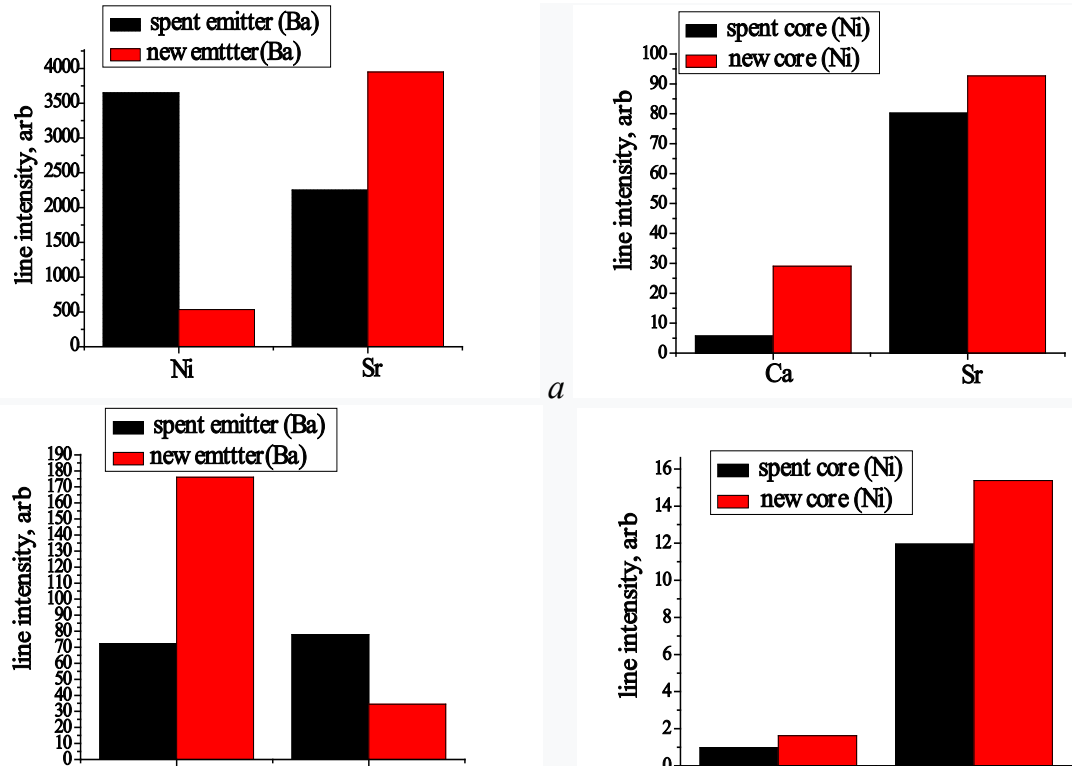

$\mathrm{Ba}$

$\mathrm{Ca}$

$a$
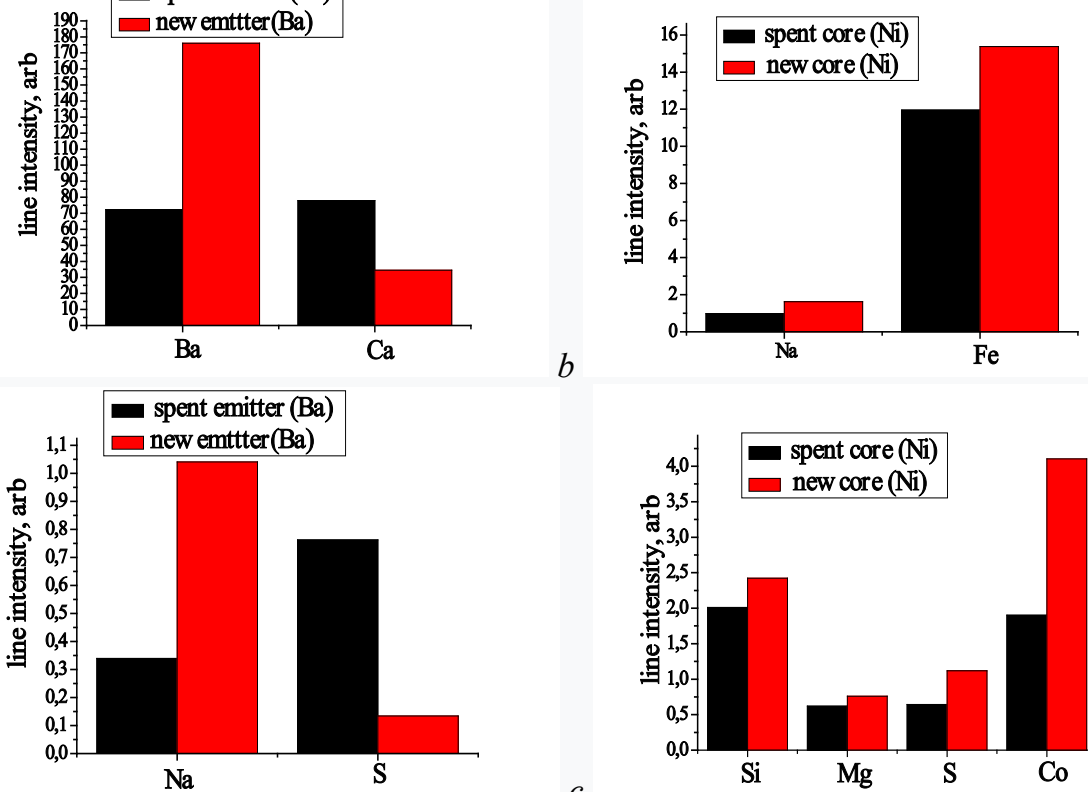

$b$

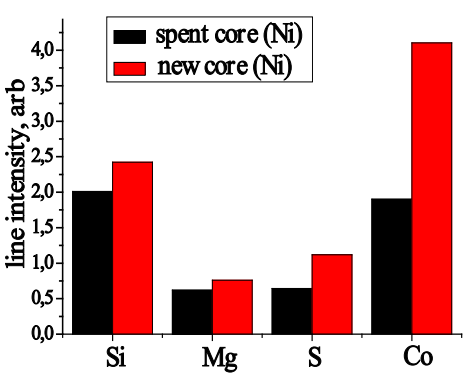

Fig. 5. Distribution of intensities of line elements in the spectra: " $a, b, c$ " -in the oxide layer, " $d$, $e, f$ " - in the core material 


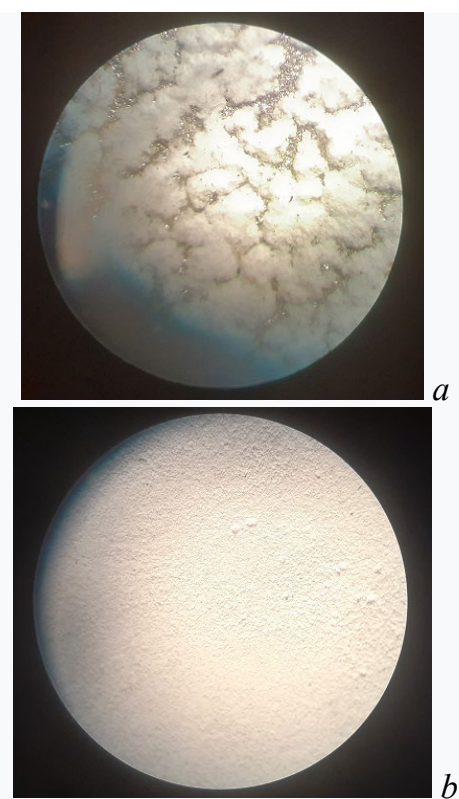

Fig. 6. The surface of the oxide layer, the increase $x 50$ " $a$ " - spent cathode, " $b$ " is the new cathode

\section{FINDINGS}

1. A complex of studies of the oxide layer and core material of cathodes with varying degrees of operating time has been carried out.

2. The possibility of using the method of X-ray fluorescence analysis to determine the degree of depletion and predicting the efficiency of the cathodes is shown.

3 . The factors determining the degradation and reduction of cathode emissions are determined.

\section{REFERENCES}

1. G.A. Kudintseva, A.I. Melnikov, A.V. Morozov, B.P. Nikonov. Thermoelectronic cathodes. M.: "Energy", 1966, 368 p.

2. B.P. Nikonov. The oxide cathode. M.: "Energy", 1979, $240 \mathrm{p}$.

3. J. Criss, L. Birks. Calculation methods for fluorescent X-ray spectrometry // Analytical Chemistry. 1968, v. 40 (7), p. 1080-1086.

4. V. Zait. Diffusion in metals. Exchange Processes with him. M.: "Publishing house of foreign literature", 1958, p. 381.

Article received 30.10.2019

\section{ИССЛЕДОВАНИЕ СОСТАВА ОКСИДНОГО СЛОЯ И КЕРНА КЛИСТРОННЫХ КАТОДОВ С РАЗЛИЧНОЙ СТЕПЕНЬЮ НАРАБОТКИ}

\section{С.А. Ванжа, Р.Н. Дронов, В.А. Мац, А.В. Медведев, В.Ю. Титов, Ю.Д. Тур, И.А. Чайка, Е.А. Ярошенко}

В соответствии с программой работ по восстановлению клистронов проведен цикл исследований, который включает в себя ренгенофлюоресцентный анализ состава слоя эмиттера и керна оксидных катодов с различной степенью наработки. Исследования проведены с целью оценки возможности использования и прогнозирования ресурса, как реставрированных, так и бывших в эксплуатации катодов. Анализ осуществлен при помощи WDXRF-спектрометра Bruker S8 TIGER (мощность рентгеновской трубки 4 кВт, Rh-катод, сила тока до 170 мА, напряжение до 60 кB), с программным пакетом Spectra Plus. Сравнительный анализ полученных данных для эмиттеров с различной степенью наработки может обеспечить достаточно достоверную оценку работоспособности и ресурса катодов.

\section{ДОСЛІДЖЕННЯ СКЛАДУ ОКСИДНОГО ШАРУ І КЕРНУ КАТОДІВ КЛІСТРОНІВ 3 РІЗНИМ СТУПЕНЕМ НАПРАЦЮВАННЯ}

\section{С.О. Ванжа, Р.М. Дронов, В.О. Мац, О.В. Медведєв, В.Ю. Титов, Ю.Д. Тур, І.О. Чайка, С.О. Ярошенко}

Згідно з програмою робіт по відновленню клістронів проведено цикл досліджень, який включає в себе ренгенофлюоресцентний аналіз складу шару емітера і керна оксидних катодів з різним ступенем напрацювання. Дослідження було проведено з метою оцінки можливості використання і прогнозування ресурсу як реставрованих, так і катодів, що були вже в експлуатації. Аналіз здійснено за допомогою WDXRFспектрометра Bruker S8 TIGER (потужність рентгенівської трубки 4 кВт, Rh-катод, сила струму до 170 мA, напруга до 60 кB), з програмним пакетом Spectra Plus. Порівняльний аналіз отриманих даних для емітерів 3 різним ступенем напрацювання може забезпечити досить достовірну оцінку працездатності і ресурсу катодів. 